\title{
Sister Mary Joseph's Nodule of a Gastric Origin: About a Case and Literature Review
}

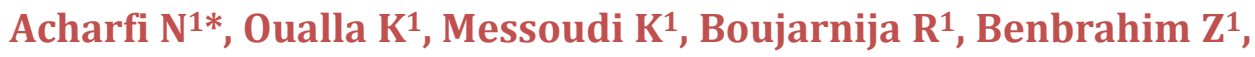 \\ Arifi S1, EL fatemi $\mathbf{H}^{2}$, Boubou $\mathbf{M}^{3}$, Bouhnoun $\mathrm{Z}^{4}$ and El Abkari $\mathbf{M}^{4}$, \\ Ibrahimi $\mathrm{A}^{4}$ and Mellas N1 \\ ${ }^{1}$ Department of Medical Oncology, Hassan II University Hospital, Morocco \\ ${ }^{2}$ Department of Pathology, Hassan II University Hospital, Morocco \\ ${ }^{3}$ Department of Radiology, Hassan II University Hospital, Morocco \\ ${ }^{4}$ Department of Gastro enterology, Hassan II Hospital, Morocco
}

\section{Case Report}

Volume 3 Issue 1

Received Date: February 01, 2019

Published Date: February 19, 2019

DOI: $10.23880 /$ mjccs-16000206

*Corresponding author: Nisrine Acharfi, Hassan II hospital university, Fez, Morocco, Tel: 0652210247; Email: nisrinacharfi@gmail.com

\section{Abstract}

The nodule of Sister Mary Joseph is a rare tumor whose origin is abdominopelvic. The prognosis is pejorative. We report the case of a patient with umbilical metastasis of a gastric adenocarcinoma treated in the medical oncology department at HASSAN II university hospital of fez, Morocco. The aim of this work is to show the rarity of this entity and describe the clinical, radiological, pathological, and prognostic features, in addition to therapeutic management.

Keywords: Sister Mary Joseph’s nodule; Adenocarcinoma; Palliative chemotherapy

\section{Introduction}

The nodule of Sister Mary Joseph is a palpable umbilical metastasis as a result of the spread of a malignant cancer in the pelvis or abdomen. The mechanism of spread of cancer cells to the umbilical lesion is still unclear but several mechanisms are suggested including hematogenous and lymphatic spread along the obliterated umbilical vein with direct transperitoneal spread. The primary tumor is often an adenocarcinoma, and rarely a squamous cell carcinoma. Digestive cancers are the most frequent primary cancers, but also gynecologic cancers can be the origin and rarely urological or respiratory malignancies. The prognosis remains pejorative because it is generally associated with other metastases especially peritoneal metastases.

\section{Case Presentation}

We report the case of 73-year-old woman, treated in the department of medical oncology at Hassan II
University hospital, in Fez, Morocco, for gastric adenocarcinoma metastatic to liver and lung. She received first line chemotherapy based on six cycles of FOLFOX. After the 6th cycle, the patient reported abdominal distension with umbilical swelling. On physical examination, a painless ulcerative and burgeoning umbilical lesion was found, with ferm consistancy and measuring $5 \mathrm{~cm}$ in its greatest diameter (Figure 1).

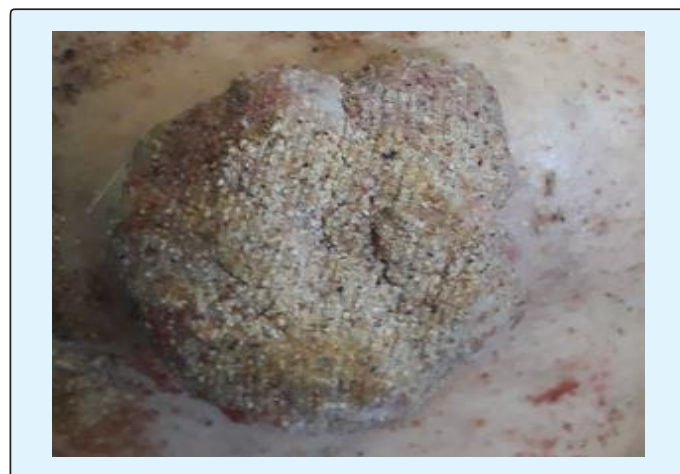

Figure 1: Sister mary joseph's nodule. 


\section{Medical Journal of Clinical Trials \& Case Studies}

A biopsy was performed and the anatomopathological study showed an adenocarcinoma. The radiological assessment showed a progression of the gastric process, in addition to progression of hepatic metastases and peritoneal carcinomatosis (Figure 2).

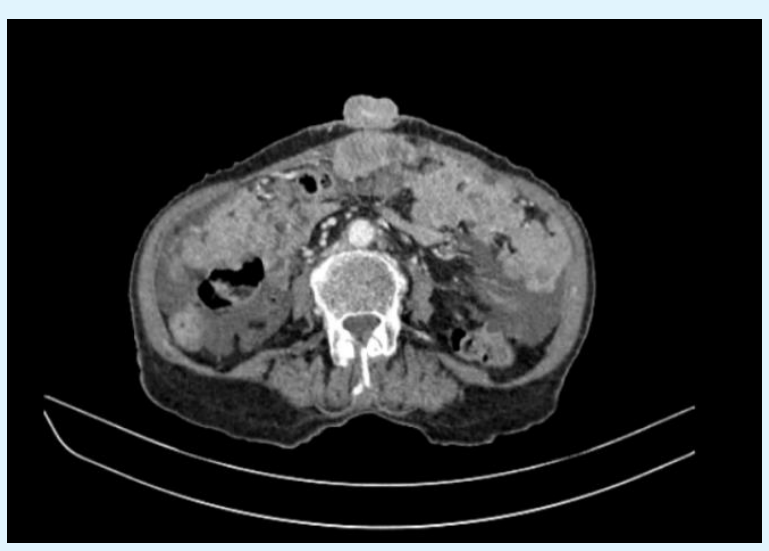

Figure 2: Abdominal CT showing hepatic metastases, peritoneal carcinomatosis with infiltration of the rectus muscle.

The tumor markers ACE and CA 19-9 were normal. Second-line chemotherapy with Paclitaxel was initiated. Evolution was marked by progression after 3 cycles. The patient presented a rapid clinical progression and died after 11 months from initial diagnosis.

\section{Discussion}

The term Nodule of Sister Mary Joseph was first described by a nurse "Sister Mary Joseph Dempsay" who accidentally discovered an umbilical nodule in a patient during preoperative abdominal preparation [1]. This eponymous was first used by Sir Hamilton Bailey in 1949 to describe the entity of umbilical metastatic lesions [2]. The sister mary joseph's nodule is a palpable nodule clinically secondary most often to an abdominopelvic tumor [3]. Its incidence is rare between 1 to 3\% [4]. The average age is 60 years without predominance of sex [5]. The digestive origin is estimated at 55\% (stomach $26 \%$, colon-rectum $10 \%$, pancreas7\%) [6,7] then comes the gynecological origin (ovary 12\%) more rarely the cervix and the endometrium [8]. In $29 \%$ of cases the etiology remains undetermined [9]. The dissemination mechanisms evoked are the direct extension by contiguity of the peritoneal lesions via the dermal vessels of the umbilicus, hematogenous (arterial and venous) lymphatic dissemination or an extension along the ligaments of embryonic origin (from the round ligament of the liver to the umbilical ligament of the urachus)[10].

Clinically, the nodule presents as umbilical induration, swelling, cracking or ulceration, painful and sometimes itchy $[10,11]$. The size of the nodule varies from 1 to 1.5 $\mathrm{cm}$ in diameter but tumors of $10 \mathrm{~cm}$ have been reported in the literature [10]. In our patient, the nodular umbilical lesion was ulcerative burgeoning and was $5 \mathrm{~cm}$ in large diameter. The formal diagnosis is based on the double pathological study: diagnosis when the umbilical nodule is isolated, thus making it possible to determine its primitive or secondary origin and for the purpose of extension assessment allowing to confirm the metastatic character of a primary tumor already known as is the case in our patient who is already followed for gastric cancer [2]. The most common histological type is adenocarcinoma in approximately $75 \%$ of cases, more rarely squamous cell carcinoma, undifferentiated cancer or carcinoid tumor $[7,10]$.

Differential diagnosis may occur with umbilical hernia, primary umbilical cancer (squamous or basal cell carcinoma, melanoma, sarcoma, adenocarcinoma) or benign umbilical tumor (pyogenic granuloma, epidermal cyst, nevus melanocytic, histiocytofibroma)[12,13]. In gastric cancers, the presence of Sister Mary Joseph's nodule is a sign of poor prognosis, palliative chemotherapy is therefore proposed to the patient or a therapeutic abstention. If it's general state is much altered [14]. For our patient, palliative second line chemotherapy was started, but she died after rapid progression.

\section{Conclusion}

Sister Mary joseph's nodule remains a rare tumor. Its metastatic nature is most often of digestive origin, thus imposing a double-purpose biopsy for diagnostic and prognostic.

\section{References}

1. Delgadillo X, Gonzalez M, Merlini M (2007) Le nodule de SœurMarie-Joseph. Schweiz Med Forum 7: 10011002.

2. S. Gharaba, Elfadil K, Samlani Z, Difaa A, Krati K, et al. (2011) Nodule de sœur marie joseph .quelles implications diagnostiques et thérapeutiques?A propos de deux cas. African Journal of HepatoGastroenterology 5(4) : 276-279. 


\section{Medical Journal of Clinical Trials \& Case Studies}

3. Gabriele R, Conte M, Egidi F, Borghese M (2005) Umbilical metastases: current viewpoint. World J Surg Oncol 3(1): 13.

4. Dubreuil A, Dompmartin A, Barjot P, Louvet S, Leroy D (19980) Umbilical metastasis or Sister Mary Joseph's nodule. Int J Dermatol 37(1): 7-13.

5. Fourati M, El Euch D, Haouet H, Boussen H, Haouet S, et al. (2004) Adénocarcinome de l'ombilic. Ann Dermatol Venereol 131: 379-381.

6. Barrow MV (1966) Metastatic tumors of the umbilicus. J Chron Dis 19: 1113-714.

7. Powell FC, Cooper AJ (1984) Sister-Mary-Joseph's nodule. A clinical and histology study. J Am Acad Dermatol 10: 610-615.

8. Piura B, Meirovitz M, Bayme M, Shaco-Levy R (2007) Sister Mary-Joseph's nodule originating from endometrial carcinoma incidentally detected during surgery for an umbilical hernia: a case report. Arch Gynecol Obstet 4(6): 385-388.

9. Turquin T, Cowpli BP, Kouame J, Kouadio K, Echimane A (1996) Métastase ombilicale des tumeurs viscérales : à propos de deux cas. Med Afr Noire 43(10): 556-558.
10. Touard JP, Lentz N, Dutronc Y, Mercier E, Sagot P, et al (2000) Métastase cutanée ombilicale révélatrice d'un adénocarcinome ovarien. Gyneco Obstetric 28(10): 719-721

11. Asmae El khadir, Wafae Hliwa, Rhimou Alaoui (2013) Métastase cutanée ombilicale révélatrice d'un adénocarcinome grêlique.A propos d'un cas. Hegel 3(4): 264.

12. Boufettal H, Hermas S, Mahdaoui S, Noun M, Samouh N (2011) Nodule de Soeur-Marie-Joseph : A propos d'un cas. Elsevier Masson. Imagerie de la Femme 21: 83-85

13. Boufettal H, Zekri H, Majdi F (2009) Endométriose ombilicale primitive. Ann Dermatol Venereol 136: 941-3.10.

14. Badri T, Fazaa B, Zermani R, Sfar R, Ben Jilani S, et al. (2005) Tumeur de l'ombilic. Ann Dermatol Venereol 132: 55-57.

15. NDiaye AR, Fall F, NDiaye B, Niang A, Dia D, et al. (2008) Un cas rare de métastase ombilicale de tumeur viscérale. Éponyme : nodule de SœurMarieJoseph. J Afr Hepato Gastroenterol 3(1): 29-31. 